retary of the Treasury, to designate and mark out the boundaries of the quarantine grounds and anchorages for vessels at the United States quarantine stations, and imposed a penalty of fine or imprisonment or both for the violation of any part of the act or any regulation made in accordance with the act.

Another section of the amendment provided for quarantine measures to apply to vessels arriving in collection districts without entering a port of the United States. This is intended particularly for fishing-smacks and other small craft which leave Cuban ports for smuggling rum and tobacco into the United States along the coast of Florida; these vessels were liable to convey infection by landing their sick on this coast.

To further aid in the enforcement of the quarantine laws the act gave authority to national quarantine officers to administer oaths.

The above law was recommended by the Committee on National Legislation of the American Medical Association, and approved, at their annual conference, held at Washington, D.C. Feb. 20 and 21, 1901, of the legislative delegates from the various states of the United States. Coneerted action in the future will, it is hoped, secure more legislation indorsed or proposed by the national conference with the legislative committees of the American Medical association.

H. I. E. JoHNSON, M.ID.

Chairman Committee on National Legislation, Amrkicax Medical Assoctation.

\section{Quarantine Against Plague.}

New Yosk, March 8, 1901.

To the Editor:- Dr. Doty is quoted by Dr. Bracken, in THE JoURNAL of March 9, p. 677 , as having said that "rats collected at New York, from coffee-carrying vessels from Rio Janeiro and Santos, during the recent outbreak of plague in those two places, were examined bacteriologically, and in no instance was there the slightest evidence of bubonic plague." I add that neither did Dr. Doty's bacteriological examination disclose bubonic plague in the body of the dead laborer on one of the lighters to which the cargo was being removed in mid-bay-who suddenly died of pneumonia. Yet the man's hands had been in direct contact with the rat-infected cargo, and had breathed into his lungs its dust. Credit is due President Murphy, of the New York Board of Health, for his firmness in not permitting the port quarantine service to unload those ships at their piers. Had that been done, some sick rats could have come ashore to infect, our sewers by their droppings, or by transferring their infected fleas to our rats. And this plague pneumonia, if the bubonie stage was delayed, might have gained its foothold here. The Hombay Medical Union elaimed that in some such way their city beeame infected from sugar cargoes from Hongkong, which were unloaded at the granary-piers, the feeding places of the Bombay rat.

Dr. Doty's position, at the time of our controversy, was wholly on the side of the coffee importers and the New York Chamber of Commerce.

Alizer' S. Ashmead, M.D.

\section{Washington's Governor and Medical Practice.} SPokane, Wash., March 4, 1901.

To the Editor:-I noted with great pleasure your very just criticisms on the conduct of Governor Thomas of Colorado, in a recent issue of The Journal, also the manner in which the profession has turned him down. I take pleasure in informing you that our state legislature has similarly rebuked John R. Rogers, the present governor of the State of Washington.

At the beginning of the present session of our legislature one of the representatives from this county, Dr. C. G. Brown, introduced a bill which was a slight improvement over our former medical act, in that it prevented osteopaths and other quacks from practicing without having been properly licensed. It also made possibie conviction of parties practicing medicine without the necessity of proving that they actually received money for the services. In addition to this, it has a provision for recognizing the licensed graduates from other states, having regular licensing bodies. This bill, after passing both houses, was vetoed by the governor in a Iong harangue on the blessings of osteopathy, which was published in all the papers in the state. The bill was immediately reconsidered, through the efforts of Dr. Brown, and has now passed both houses with a safe majority, and is a law. Yours very respectfully,

$$
\text { C. l'. Tromas, M.D. }
$$

LTuk Jotksal of March!) editorialiy commented on this action of Washington's governor, the news of the above reprimand to his reto having been received after tinat issue of THE Jocriat. was on the press. ED.]

\section{Subscriptions for Ollier Monument.}

To the Editor:-The undersigned constitute a committe similar to those formed in seceral European countries for the purpose of receiving subscriptions for a monument commemorative of the distinguished seintific services of Prof. Leopold Ollier. Among the members of these committees are Lord Lister, Professors von Bergmann, Czerny, Durante and other leading men. The municipality of the city of Lyons has dedicated an open space adjacent to quarters of the various academic faculties on the border of the Rhone, named in his honor "Place Leopold Ollier."

The profession of this country is well aware of the great services rendered by Professor Ollier, especially in the domain of plastic and osceous surgery. His labors have been most fruitful in the domains of surgery, of physiology and pathology.

The committee hopes to raise not less than $\$ 1000$ as a testimonial from the profession of America. Check should be forwarded to Dr. W. W. Keen, I729 Chestnut street, Philadelphia, at as a carly a date as possible.

Commite:---Robert Abbe and William T. Bull, New York; P. S. Conner, Cincinnati, Ohio; A. T. Cabot, Boston; Howard A. Kelly, Baltimore; W. W. Keen, Philadelphia, Rudolph Matas, New Orleans; Wm. J. Mayo, Rochester, Minn.; W. F. McNutt, San Francisco; Roswell Park, Buffalo, N. Y.; Clayton Parkhill, Denver, Colo.; Maurice H. Richardson. Boston: Nicholas Senn, Chicago.

\section{Married.}

Geonge A. Brockitox, M.D, Oxnard, Cal., to Miss Mary livingston, of San Francisco, Cal.

Wuluakr A. Caver, M.D., Hazelwood, Pittsburg, Pa., to Miss Margaret Elizabeth Wircback, of Monessen, Pa., February 25.

GEORGE W. MCCor, M.D., U. S. M.-H. Service, formerly of Bristol, now stationed in San Francisco, Cal., to Miss Fidith Miller, of Pennsylvania, at San Francisco.

\section{Deaths and Dbituaries.}

\section{Richard J. Dunglison, M.D.}

Dr. Richard James Dunglison died at his home in Philadelphia, March 5, from dropsy and heart failure, following an attack of pneumonia a year ago. He was born in Baltimore, Nov. 13, 1834, and came of a medical family, his father being Dr. Robley Dunglison, professor of institutes of medicine and medical jurisprudence in Jefferson Medieal College, and his grandfather, Mr. John Leadam, a noted surgeon of London, England. He was graduated from Jefferson Medical College in 1856 , but after a few years relinquished the practice of medicine for the field of medical literature. He was editor of two editions of "Dunglison's Medical Dictionary," and of the "History of Medicine," of which lis father was the author ; was editor of Dunglison's College and Clinical Record for fifteen years, one of the original editors of the Philadelphia Medical Times, for several years Philadelphia correspondent of the Medical Times and Gazette of Jondon, and a frequent contributor to the medical literature. He was the author of the "Practitioners' Reference Book;" "A Handbook of Diagnosis, Therapeutics and Dietetics"; "A New School of Physiology and Hygiene"; "An Elementary Physiology and Hygiene," and "The Present Treatment of Diseases." He also translated Tuersant's "Surgica! 